\title{
Continuous flow process to make fermented cassava starch substitute: I. Physicochemical and functional properties
}

\author{
Produção de sucedâneo de polvilho azedo em processo \\ contínuo: I. Propriedades físico-químicas e funcionais
}

\author{
Vitor Brito ${ }^{1 *}$ (1), Renata Santos², Jeniffer Narcisa-Oliveira², Ivo Demiate ${ }^{3}$, Marney Cereda² (D) \\ ${ }^{1}$ Universidade para o Desenvolvimento do Estado e da Região do Pantanal (UNIDERP), Departamento de \\ Produção e Gestão Agroindustrial, Campo Grande/MS - Brasil \\ 2Universidade Católica Dom Bosco (UCDB), Departamento de Ciências Ambientais e Sustentabilidade \\ Agropecuária, Campo Grande/MS - Brasil \\ ${ }^{3}$ Universidade Estadual de Ponta Grossa (UEPG), Ponta Grossa/PR - Brasil
}

*Corresponding Author: Vitor Brito, Universidade para o Desenvolvimento do Estado e da Região do Pantanal (UNIDERP), Departamento de Produção e Gestão Agroindustrial, Av. Alexandre Herculano, 1400, CEP: 79035-470, Campo Grande/MS - Brasil, e-mail: britovhs@gmail.com

Cite as: Brito, V., Santos, R., Narcisa-Oliveira, J., Demiate, I., \& Cereda, M. (2021). Continuous flow process to make fermented cassava starch substitute: I. Physicochemical and functional properties. Brazilian Journal of Food Technology, 24, e2020017. https://doi.org/10.1590/1981-6723.01720

\begin{abstract}
The Brazilian fermented cassava starch (polvilho azedo) is prized as a raw material for fast food preparation. Its traditional production by natural fermentation and exposure to sunlight favors contamination and impurities, in addition to depending on the climate. The literature explains the characteristic expansion of polvilho azedo as a reaction of the lactic acid produced during fermentation and sun radiation. With the aim to evaluate a commercial continuous flow process, a modular lamp (UV-C) was evaluated to substitute exposure to sunlight. The selected doses were 1,000, 5,000 and 10,000 Joules per liter $\left(\mathrm{J}^{-1}\right)$. Native cassava starch suspension in water at $6 \%$ (dry basis) was adjusted to $4 \%$ lactic acid (dry basis) and exposed to UV-C radiation: (a) without lactic acid, (b) with lactic acid reaction for 1 hour, (c) with ultraviolet radiation, in addition to the combination of $(a c)$ and $(b c)$. The results showed that only the combination of acidification and ultraviolet radiation $(b c)$ allows an expansion $\left(11 \mathrm{~cm}^{3} \mathrm{~g}^{-1}\right)$ higher than the commercial polvilho azedo $\left(8.24 \mathrm{~cm}^{3} \mathrm{~g}^{-1}\right)$ adopted as standard. It was concluded that is possible to achieve a substitute for fermented cassava starch by acidification of native cassava starch with lactic acid in a continuous flow system starting with a dose around $5,000 \mathrm{~J} \mathrm{I}^{-1}$ of UV-C radiation.
\end{abstract}

Keywords: Modified starch; Carboxyl; Cassava; Lactic acid; Quality.

\section{Resumo}

O amido de mandioca fermentado (polvilho azedo) é valorizado como matéria-prima para o preparo de fast food. Sua produção tradicional por fermentação natural e exposição ao sol favorece a contaminação e impurezas, além de depender das condições climáticas. A literatura explica a expansão característica do polvilho azedo como uma reação do ácido lático produzido durante a fermentação e a radiação solar. Com o objetivo de avaliar um processo comercial em fluxo contínuo, uma lâmpada modular (UV-C) foi empregada para substituir a exposição à luz solar. 
As doses selecionadas foram 1.000, 5.000 e 10.000 Joules por litro $\left(\mathrm{J}^{-1}\right)$. A suspensão de amido de mandioca nativo em água a 6\% (base seca) foi ajustada para 4\% de ácido lático (base seca) e exposta à radiação UV-C: (a) sem ácido lático, (b) com reação de ácido lático por 1 hora, (c) com radiação ultravioleta, além da combinação de (ac) e (bc). Os resultados mostraram que apenas a combinação de acidificação e radiação ultravioleta (bc) permite uma expansão $\left(11 \mathrm{~cm}^{3} \mathrm{~g}^{-1}\right)$ superior ao polvilho azedo comercial $\left(8,24 \mathrm{~cm}^{3} \mathrm{~g}^{-1}\right)$ adotado como padrão. Concluiu-se que é possível obter um sucedâneo para o amido fermentado pela acidificação do amido de mandioca nativo com ácido lático em um sistema de fluxo contínuo a partir de uma dose em torno de $5.000 \mathrm{~J} \mathrm{I-1}$ de radiação UV-C.

Palavras-chave: Amido modificado; Carboxilas; Mandioca; Ácido lático; Qualidade.

\section{Introduction}

Among the products obtained from cassava, fermented cassava starch, known in Brazil as polvilho azedo, stands out as a type of modified starch that has as main attributes a characteristic flavor and expansion property (Cereda, 1993; Demiate \& Kotovicz, 2011).

The expansion property of fermented cassava starch in the oven without using yeast or chemical leavening (baking soda) is unique. This expansion has attracted researchers not only because the snake's preparation with it does not require extrusion, which is expensive, but also because it allows as an offer of baked products without gluten to the market (Brito \& Cereda, 2015).

Fermented cassava starch was traditionally used at home or in small bakeries, but its main product, the cheese bread, became a fast food. It is a baked product which can be consumed with or without various fillings (Demiate \& Kotovicz, 2011), which requires greater quality control.

The fermentation process yields organic acids with the predominance of lactic acid, which causes partial depolymerization of the polymer chains (Demiate et al., 1999). Exposure to solar ultraviolet (UV) radiation at the drying stage promotes oxidation and all of these modifications result in a plastic dough with baking expansion (Cereda, 1993; Plata-Oviedo \& Camargo, 1998).

Fermented cassava starch is not uniform and presents contamination by dust, insects and microorganisms. When polvilho azedo is produced in small scale industries, it may show a variable quality (Brito \& Cereda, 2015), which makes the constant search for improvements in the production process attractive (Vatanasuchart et al., 2005).

To explain polvilho azedo's expansion, the hypothesis is that the reaction of starch with lactic acid catalyzed by UV radiation is instantaneous, but delayed by the slow infiltration of solar UV radiation into the fermented cassava starch on a drying surface. In small industries, the product is revolved by hand, and as this radiation has little penetration, only slightly thicker layers are exposed to solar UV radiation at a time (Cereda, 1993; Franco et al., 2010).

The published research results confirm the changes associated with oxidative degradation of starch by the concomitant use of lactic acid and artificial UV radiation, always provided by lamps set on surfaces where acidified cassava starch is exposed (Vatanasuchart et al., 2005; Marcon et al., 2009; Franco et al., 2010). Moreover, the batch process is difficult to apply at an industrial level and hinders quality standardization. The only way to measure the quality of cassava starch is to use a specific volume in $\mathrm{cm}^{3} \mathrm{~g}^{-1}$ (Brito \& Cereda, 2015).

In the production of oxidized starches by a continuous system, Tethool et al. (2012) used a suspension of sago starch (Metroxylon sago Rottb) in hydrogen peroxide irradiated with UV (100 to $400 \mathrm{~nm}$ ) for 15 minutes, having obtained a specific volume of $8.65 \mathrm{~cm}^{3} \mathrm{~g}^{-1}$ and an increase of $0.44 \%$ in carboxyl groups in the samples. Dewi et al. (2014) employed UV-C (100 to $250 \mathrm{~nm})$ and found a higher carboxyl content $(0.93 \%)$, but the expansion power of the baked dough presented much lower values $\left(3.8 \mathrm{~cm}^{3} \mathrm{~g}^{-1}\right)$. 
This study evaluated a substitute for polvilho azedo produced in a commercial continuous flow system with lamps generating UV radiation type C $(235-280 \mathrm{~nm})$ in a suspension of $6 \%$ cassava starch in water adjusted to $4 \%$ of acid lactic (P.A.) on starch dry base and 1 hour as reaction time.

\section{Materials and methods}

\subsection{Starch sample}

We used two types of commercial cassava starch: Native starch from Amidos Paranaense ${ }^{\circledR}$ as the substrate of the tests and a sample of polvilho azedo Yoki ${ }^{\circledR}$ as the quality standard.

\subsection{Equipment for UV-C treatment in a continuous flow system}

For the treatment with ultraviolet (UV) radiation, a modular system of Germetec ${ }^{\circledR}$ Ultraviolet \& Infrared Technology Ltda. (Rio de Janeiro - Brazil) was used. A commercial system (reactor + lamp) used for continuous treatment of water was selected. The inner wall of the lamp and the quartz glass outer wall forms a chamber through which the liquid to be treated flows. The reactor model GPJ-MP UV contains a mediumpressure mercury vapor arc lamp of 1,600 W, which emits radiation between 235 and $280 \mathrm{~nm}$. Both the system and the starch treatment were registered under patent application BR10201402768.

In the modular system, it is possible to add or exchange lamps in sequence and adjust the radiation doses depending on the treatment duration. The lamp used has $32 \mathrm{~mm}$ in diameter and $335 \mathrm{~mm}$ in length, with an internal diameter of $50 \mathrm{~mm}$ and a length of $350 \mathrm{~mm}$, providing a useful volume of $417.79 \mathrm{~mL}$. A stainlesssteel cover protects the set. The UV lamp lifetime is continuously marked at every use by a control panel. With the lamp power and the useful volume, the dose was expressed per liter of suspension considering the time in seconds to pass and recirculate the starch suspension through the lamp.

The suspension was placed in a plastic container (1) under mechanical agitation to keep the starch from settling. The dose of 1,000 Joules per liter $\left(\mathrm{J}^{-1}\right)$ corresponded to 48 seconds (or 1 lamp), the dose of 5,000 $\mathrm{J}^{-1}$ corresponded to 240 seconds (or 5 lamps), and the dose of 10,000 $\mathrm{J} \mathrm{l}^{-1}$, to 480 seconds (10 lamps).

\subsection{Experimental design}

The experimental design is organized in four treatments. The independent variables were cassava starch samples treatment with lactic acid and exposed to 3 doses of UV-C radiation. The dependent variable was the quality of the product, measured by expansion in the oven expressed by score of specific volume of baked dough (Brito \& Cereda, 2015). A commercial fermented cassava starch was used as standard and a sample treated with acid lactic without UV-C treatment was used as whiteness.

The four treatments were: a) native cassava starch without acidification, (b) acid lactic and (c) 3 doses of ultraviolet radiation, in addition to compounds (ac) and (bc). The UV-C doses were calculated in 1,000, 5,000 and $10,000 \mathrm{~J}^{-1}$.

All tests were conducted to simulate the conditions of the cassava starch industry, in which the starch slurry concentration in water is $6 \%$ on a dry basis (DB) after extraction and before the first centrifuge. The lactic acid concentration was established at $4 \%$ in relation to the native starch in dry matter. Therefore, for every 1001 of water, $6 \mathrm{~kg}$ of starch and $240 \mathrm{~mL}$ of Lactic Acid Synth ${ }^{\circledR}$ PA were used for 1 hour of reaction.

The 20-liter suspension was placed into the plastic container at $20^{\circ} \mathrm{C}$ and the residence time was set to 1 hour. At the same time, the acidified suspension was introduced into the reservoir and partly fed by ultraviolet radiation treatment by a continuous flow pump. 


\subsection{Material preparation for characterization analyses}

The starch slurry samples from each treatment were collected, filtered on paper filter using a Kitassato with the aid of a tight vacuum (Tecnal ${ }^{\circledR}$ TE-058). The wet mass retained was dried in an oven (Marconi ${ }^{\circledR}$ MA 037, Piracicaba - Brazil) with renewal forced air at $45^{\circ} \mathrm{C}$ for 48 hours, followed by grinding in a mortar.

\subsection{Expansion power expressed by specific volume}

The specific volume was measured according to Brito \& Cereda (2015). The mixture of starch and water was drawn directly on the silicon mold (Tupperware ${ }^{\circledR}$ capacity of $65 \mathrm{~mL}$ ) at a proportion of 1:1, i.e. $5 \mathrm{~mL}$ of drinking water ( $\mathrm{pH}$ 6.81) was added to $5 \mathrm{~g}$ of each starch sample (DB), and the mixture was homogenized with a spatula. The molds with the starch dough were placed directly into an electric oven of the Diplomat Autoforno Electric ${ }^{\circledR}$ brand at $200{ }^{\circ} \mathrm{C}$ for 20 minutes. The weight of the samples was obtained from a precision balance, and the volume, by seed displacement. The specific volume corresponding to the expansion power was calculated as the ratio of the volume $\left(\mathrm{cm}^{3}\right)$ and weight $(\mathrm{g})$ of each sample with the results expressed in $\mathrm{cm}^{3} \mathrm{~g}^{-1}$.

\subsection{Characterization of the substitute of fermented cassava starch}

The substitute of fermented cassava starch was characterized by the following analyses: humidity, in percentage (\%), by the Official Methods Analysis (Association of Official Analytical Chemists, 1997); and hydrogen potential $(\mathrm{pH})$ and carboxyl content, according to Smith \& Paschall (1967), expressed as a percentage.

\subsection{Rapid Visco Analyzer Viscosity (RVA)}

The apparent viscosity of the starch samples submitted to the treatments was determined in Rapid Visco Analyzer (RVA-4 model, Newport Scientific ${ }^{\mathrm{TM}}$, Narabeen, Australia). The samples ( $8 \% \mathrm{DB}$ ) were dispersed in deionized water with a metal beaker, followed by coupling to the system. The equipment was programmed to start the cycle at $50^{\circ} \mathrm{C}$ and sit for 1 minute under this temperature. After this period, the sample was heated at a rate of $6{ }^{\circ} \mathrm{C}$ per minute to reach $95{ }^{\circ} \mathrm{C}$, where it remained for 5 minutes. Then, the slurry was cooled to $50{ }^{\circ} \mathrm{C}$ (at a rate of $6{ }^{\circ} \mathrm{C}$ per minute) and remained at this temperature until the end of the analysis, which occurred 23 minutes afterwards as per the manufacturer's recommendations (Newport Scientific, 1998). The suspension was subjected to rotational shear at $160 \mathrm{rpm}$ throughout the experiment. The properties of the starch pastes were determined using software Thermocline Windows ${ }^{\circledR}$ and the results were expressed in $\mathrm{cP}$ (centipoise).

\subsection{Paste Transparence}

Transparency was evaluated indirectly by transmittance (T\%) using spectrophotometry at $650 \mathrm{~nm}$ according to Craig et al. (1989). To measure the transparency, a starch suspension was prepared in water at $1 \%(\mathrm{~W}: \mathrm{V}$, dry basis) and placed in a boiling water bath for 30 minutes. The samples were evaluated immediately (hot transparency) and after 24 hours (cold transparency) and the results were expressed as a percentage of transmittance. As standard, was used distilled water.

\subsection{Statistical analysis}

With the results with normal distribution, the mean and standard deviation $(\sigma)$ were established. The means were compared by the Tukey test at $5 \%$ probability using the Statistica 7.0 software (StatSoft, Inc., 2008). 


\section{Results and discussion}

Tables 1, 2 and 3 present the quality of the commercial polvilho azedo (standard), native cassava starch, and the other modified cassava starches. The same tables also present the characterization of the native and commercial fermented cassava starch and the effect of the variables on the physicochemical and functional properties of the cassava starches after the treatments. The native cassava starch presented the lower specific volume of all of the samples, corroborating the literature (Dias et al., 2007; Marcon et al., 2009; Brito \& Cereda, 2015) that reports that the cassava starch has no expansion power without baking soda, yeast or extrusion.

The expansion power was considered as the quality index for fermented cassava starch, and the aspect of the baked dough is also an important characteristic. Table 1 shows that the commercial fermented cassava starch presented the higher specific volume, similar only to samples treated with lactic acid under UV-C radiation in all of the doses evaluated.

The native starch (NS) sample presented no expansion (Table 1), as shown by the mark left at the base of the silicone mold in all of the baked doughs, with differences in patterns only at the top as an effect of the treatments. The sample of commercial polvilho azedo (PA) presented more vertical expansion with a slight deformation at the center and the top. The samples treated only with lactic acid (LA) presented a small volume and rounded shape. Similar shapes but with highest values are also visible in the samples treated only with UV-C radiation at doses of 1,000 and 5,000 $\mathrm{J}^{-1}$. The research data do not yet allow to understand these differences.

Table 1. Expansion power by specific volume (DB), humidity, $\mathrm{pH}$ (DB), and carboxyl (DB) of native cassava starch, commercial polvilho azedo (fermented starch) and samples treated with lactic acid and/or ultraviolet (UV) radiation type $C$ in a continuous flow system.

\begin{tabular}{|c|c|c|c|c|}
\hline \multirow{2}{*}{ Sample } & Expansion & Humidity & pH & Carboxyl \\
\hline & $\mathrm{cm}^{3} \mathrm{~g}^{-1}$ & $\mathrm{~g} 100 \mathrm{~g}^{-1}$ & $-\log [\mathrm{H}+]$ & $\%$ \\
\hline Native cassava starch & $1.94 \pm 0.25 \mathrm{c}$ & $10.53 \pm 0.09 \mathrm{~b}$ & $5.68 \pm 0.04 \mathrm{c}$ & $0.00 \pm 0.03 \mathrm{~d}$ \\
\hline Commercial polvilho azedo & $8.24 \pm 1.65 \mathrm{a}$ & $10.60 \pm 0.35 \mathrm{~b}$ & $4.75 \pm 0.01 \mathrm{~d}$ & $0.16 \pm 0.00 \mathrm{a}$ \\
\hline Starch acidified with lactic acid & $4.62 \pm 0.26 \mathrm{~b}$ & $11.25 \pm 0.25 \mathrm{~b}$ & $3.18 \pm 0.00 \mathrm{~d}$ & $0.06 \pm 0.00 \mathrm{c}$ \\
\hline \multicolumn{5}{|c|}{ Submitted to ultraviolet radiation type $\mathrm{C}$ without acidification } \\
\hline $1000 \mathrm{~J} \mathrm{l}^{-1}$ & $3.58 \pm 0.47 \mathrm{c}$ & $13.65 \pm 0.13 \mathrm{a}$ & $5.92 \pm 0.00 \mathrm{c}$ & $0.09 \pm 0,00 \mathrm{~b}$ \\
\hline $5000 \mathrm{~J} \mathrm{l}^{-1}$ & $9.32 \pm 3.14 \mathrm{a}$ & $8.30 \pm 0.09 \mathrm{c}$ & $6.16 \pm 0.09 \mathrm{~b}$ & $0.11 \pm 0.00 \mathrm{~b}$ \\
\hline $10000 \mathrm{~J}^{-1}$ & $2.38 \pm 0.40 \mathrm{c}$ & $10.55 \pm 1,42 \mathrm{~b}$ & $7.25 \pm 0.00 \mathrm{a}$ & $0.06 \pm 0,03 \mathrm{~b}$ \\
\hline \multicolumn{5}{|c|}{ Submitted to ultraviolet radiation type $\mathrm{C}$ with acidification by lactic acid } \\
\hline $1000 \mathrm{~J} \mathrm{l}^{-1}$ & $9.34 \pm 0.89 \mathrm{a}$ & $13.66 \pm 0.21 \mathrm{a}$ & $4.23 \pm 0.01 \mathrm{~d}$ & $0.08 \pm 0.03 \mathrm{~b}$ \\
\hline $5000 \mathrm{~J} \mathrm{l}^{-1}$ & $11.29 \pm 1.47 \mathrm{a}$ & $13.68 \pm 0.20 \mathrm{a}$ & $4.62 \pm 0.00 \mathrm{~d}$ & $0.09 \pm 0.03 \mathrm{~b}$ \\
\hline $10000 \mathrm{~J} \mathrm{I}^{-1}$ & $11.99 \pm 0.95 \mathrm{a}$ & $13.13 \pm 0.06 \mathrm{a}$ & $4.88 \pm 0.04 \mathrm{~d}$ & $0.14 \pm 0.03 \mathrm{~b}$ \\
\hline
\end{tabular}

In each column, the means values followed by the same letter do not differ by the Tukey test at $5 \%$ probability.

Only the sample treated with lactic acid followed by radiation presented an expansion power equivalent to that of the commercial polvilho azedo (PA) with an expansion shape as a mushroom both horizontally and vertically. The dose of 5,000 $\mathrm{J} \mathrm{l}^{-1}$, although providing expansion, presented a misshapen appearance by surface deformation. The sample from the treatment with both lactic acid and 5,000 $\mathrm{J}^{-1}$ presented the best appearance, with a characteristic constriction in the center.

The use of extreme radiation doses $\left(1,000\right.$ or $\left.10,000 \mathrm{~J}^{-1}\right)$ alone on native starch caused an insufficient effect. These results corroborate the results found in the literature about the influence of ultraviolet radiation on the expansion and dough properties.

The values of expansion, shape, and appearance of the baked dough in the treatments with UV-C previously acidified with lactic acid starch did not differ from the standard commercial polvilho azedo. It is possible to conclude that the use of both lactic acid and UV-C treatment may develop the expansion power in native cassava starch.

Several authors have reported high values of expanding power in static systems; however, they reported the same values obtained with mechanized revolving of the starch to increase the surface under treatment. Most authors having 
researched fermented cassava starch improving process performed manual spreading of starch on surfaces. With this method, Franco et al. (2010) obtained an expansion power of $8.08 \mathrm{~cm}^{3} \cdot \mathrm{g}^{-1}$ with 10 minutes of irradiation, whereas Vatanasuchart et al. (2003) obtained $12.23 \mathrm{~cm}^{3} \cdot \mathrm{g}^{-1}$ for acidified cassava starch irradiated with UV type B or C; however, this result was achieved with seven hours of radiation exposure.

In the continuous system using the commercial equipment proposed in this work, an expansion of about $12 \mathrm{~cm}^{3}$ $\mathrm{g}^{-1}$ was also obtained; it is equivalent to the best values of the static system reported. This result was achieved with a significant shorter time of 240 seconds of UV-C treatment, which would be equivalent to five lamps in line. These results are superior to the $8.65 \mathrm{~cm}^{3} \mathrm{~g}^{-1}$ reported by Tethool et al. (2012), who worked with sago starch (M. sago) previously oxidized with hydrogen peroxide and treated with UV radiation in a continuous system afterwards.

Another problem affecting the comparison of results is the use of different methods to measure the expansion power - some still use complex raw materials, such as cheese and milk. To overcome this problem, in this work we used a newly described methodology, which is simpler and reproducible (Brito \& Cereda, 2015).

With promising results for a continuous system, it is very important to characterize the substitutive obtained and compare it with the commercial polvilho azedo adopted as standard and with other substitutes. The results for characterization are shown in Table 1. The moisture content of the samples is not an important criterion to compare the substitutes because it can be adjusted after the treatment to comply with the current legislation, but the acidity $\mathrm{pH}$ shows a pattern that may represent the effect of the treatments.

The $\mathrm{pH}$ of native cassava starch was 5.68, and the commercial polvilho azedo adopted as standard showed low $\mathrm{pH}$ (4.75), which is a characteristic of the product and is related to the organic acids formed during fermentation (Brito \& Cereda, 2015). In addition, the differences in acidy values observed for the treated samples are a consequence of deliberate acidification with lactic acid. But for the samples of cassava starch that received lactic acid and subsequently were submitted to UV-C treatment, acidity should not be altered; however, this was not the case. The samples submitted to the treatment with UV radiation in three doses presented a gradual and significant increase in the $\mathrm{pH}$ value compared to native starch (Table 1) due to lactic acid loss. The same phenomenon did not occur with the samples irradiated with UV-C which had been previously acidified (treatments $\mathrm{b}$ and $\mathrm{c}$ ).

The $\mathrm{pH}$ values in the samples submitted to both acidification (b) and UV-C radiation (c) did not differ from that of commercial polvilho azedo but were significantly lower than the values presented by the native starch and higher than the ones found for the sample treated with lactic acid (a) alone. The lower values may be explained by the lactic acid molecule or a part of it grafting on glucose structure. A similar grafting effect was reported for acetic acid and starch reaction by Kumar et al. (2014).

The treatment with UV-C radiation caused an increase of $0.11 \%$ of carboxyl groups and $5.0 \%$ in specific volume, but $4.62 \mathrm{~cm}^{3} \mathrm{~g}^{-1}$ represents a big difference from the expansion of commercial fermented cassava starch adopted as standard. However, the carboxyl content does not follow the variation observed for the expansion power, reducing the importance of this analysis to explain the functional properties of polvilho azedo and its substitute, as show the results obtained by Dewi et al. (2014).

These results emphasize that only the expansion power characterizes the quality of commercial sour cassava starch and its substitute obtained in a continuous process. The other analyses (Table 2) only show that the variables may alter the functional properties as the viscosity caused by the treatment compared to the standard of commercial polvilho azedo.

The sample of native cassava starch was characterized by a peak viscosity of $1,233 \mathrm{cP}$, breaking of 380 and retrogradation tendency of $573 \mathrm{cP}$. The sample with the closest value was the one acidified and irradiated at 10,000 J $1^{-1}$, which did not differ from the standard polvilho azedo, and therefore confirms the expansion results. The literature shows that only the acid treatment may affect the viscosity profile (Bertolini et al., 2000; Kumar et al., 2014), which may have been caused by partial depolymerization of starch after the treatment with lactic acid and photochemical reaction at a higher dosage. In the specific case of polvilho azedo and its substitutive, the molecular structural changes result in variations of the paste properties (Demiate et al., 2000; Vatanasuchart et al., 2003). 
Table 2. Critical points of paste viscosity $(8 \% \mathrm{DB})$ of native cassava starch and polvilho azedo (fermented starch), and samples treated with lactic acid and/or ultraviolet radiation type $C$ in a continuous flow system.

\begin{tabular}{|c|c|c|c|}
\hline \multirow[b]{2}{*}{ Sample } & \multicolumn{3}{|c|}{ Viscosity (cP) } \\
\hline & Peak & Break & $\begin{array}{c}\text { Retrogradation } \\
\text { tendency }\end{array}$ \\
\hline Native cassava starch & $2782 \pm 1.98 \mathrm{a}$ & $851 \pm 3.07 \mathrm{a}$ & $1677 \pm 0.17 \mathrm{a}$ \\
\hline Commercial polvilho azedo & $1233 \pm 0.46 \mathrm{~b}$ & $380 \pm 1.67 \mathrm{c}$ & $573 \pm 3.33 \mathrm{~d}$ \\
\hline Starch acidified with lactic acid & $849 \pm 0.33 b$ & $80 \pm 2.95 \mathrm{~d}$ & $135 \pm 8.94 \mathrm{e}$ \\
\hline \multicolumn{4}{|c|}{$\begin{array}{l}\text { Submitted to ultraviolet radiation type } \mathrm{C} \text { without acidification } \\
\end{array}$} \\
\hline $1000 \mathrm{~J} \mathrm{H}^{-1}$ & $2990 \pm 0.64 \mathrm{a}$ & $851 \pm 2.07 \mathrm{a}$ & $1670 \pm 0.38 \mathrm{a}$ \\
\hline $5000 \mathrm{~J} \mathrm{l}^{-1}$ & $2339 \pm 0.18 \mathrm{a}$ & $1071 \pm 3.43 \mathrm{a}$ & $1670 \pm 1.83 \mathrm{a}$ \\
\hline $10000 \mathrm{~J} \mathrm{l}^{-1}$ & $2161 \pm 1.11 \mathrm{a}$ & $676 \pm 0.98 \mathrm{~b}$ & $1179 \pm 2.22 \mathrm{~b}$ \\
\hline \multicolumn{4}{|c|}{ Submitted to ultraviolet radiation type $C$ with acidification by lactic acid } \\
\hline $1000 \mathrm{~J} \mathrm{l}^{-1}$ & $2802 \pm 0.91 \mathrm{a}$ & $310 \pm 2.5 \mathrm{c}$ & $821 \pm 2.32 \mathrm{c}$ \\
\hline $5000 \mathrm{~J}^{-1}$ & $2083 \pm 1.77 \mathrm{a}$ & $394 \pm 3.05 \mathrm{c}$ & $599 \pm 8.50 \mathrm{~d}$ \\
\hline $10000 \mathrm{~J} \mathrm{I}^{-1}$ & $1238 \pm 2.74 b$ & $315 \pm 10.98 \mathrm{c}$ & $528 \pm 13.25 \mathrm{~d}$ \\
\hline
\end{tabular}

In each column, means followed by the same letter do not differ by Tukey test at $5 \%$ probability.

The treatment that most approximated the viscosity pattern of commercial fermented cassava starch was the one with lactic acid followed by UV-C radiation at 10,000 $\mathrm{J} \mathrm{l}^{-1}$. This shows that although the viscosity is an important characteristic of starch and its application, it should not be considered as having a high impact on the quality factor.

The increase in viscosity of the samples treated with lactic acid followed by the application of UV radiation can be attributed to the great formation of hydrogen bonds by photocrosslinking (Fiedorowicz et al., 1999; Bhat \& Karim, 2009) or a stronger type of link, which could also explain the baked dough pattern. The viscosity measurement seems to be more appropriate than the carboxylic analysis to evaluate the modifications of the starch in the production of a substitute for polvilho azedo. Due to the highest amount of carboxylic groups (Table 1), they tend to keep the chains separated, reducing the retrogradation tendency in the hot starch paste (Table 2) (Jyothi et al., 2005) and increasing the transparency property (Table 3). The transparency of the hot paste was greater than the cold one, which was expected and is explained by a structural reorganization of the amylose and amylopectin molecules in a retrogradation phenomenon (Hoover, 2001; Silva et al., 2008).

As to the results obtained for $\mathrm{pH}$ variation, the samples followed the same order when UV radiation was used, which allows us to conclude that the higher the UV-C dose, the higher the transparency of the paste, both on hot and cold conditions, when retrogradation increases (Table 3).

Table 3. Transparency (1\% DB) of native cassava starch and polvilho azedo (fermented starch) and samples treated with lactic acid and/or UV radiation type $C$ in a continuous flow system.

\begin{tabular}{ccc}
\hline \multirow{2}{*}{ Sample } & \multicolumn{2}{c}{ Transparence (T\%) } \\
\cline { 2 - 3 } & Paste at 80 ${ }^{\circ} \mathbf{C}$ & Paste at 20 ${ }^{\circ} \mathbf{C}$ \\
\hline Native cassava starch & $44.47 \pm 0.06 \mathrm{dA}$ & $43.63 \pm 0.06 \mathrm{eA}$ \\
\hline Commercial polvilho azedo & $63.20 \pm 0.00 \mathrm{bA}$ & $62.10 \pm 0.00 \mathrm{bA}$ \\
\hline Starch acidified with lactic acid & $72.90 \pm 0.00 \mathrm{aA}$ & $71.00 \pm 0.00 \mathrm{aA}$ \\
\hline Submitted to ultraviolet radiation type $\mathbf{C}$ without acidification \\
\hline $1000 \mathrm{~J} \mathrm{I}^{-1}$ & $32.10 \pm 0.00 \mathrm{eB}$ & $41.73 \pm 0.06 \mathrm{eA}$ \\
\hline $5000 \mathrm{~J} \mathrm{l}^{-1}$ & $55.73 \pm 0.00 \mathrm{cA}$ & $54.73 \pm 0.00 \mathrm{cA}$ \\
\hline $10000 \mathrm{~J} \mathrm{l}^{-1}$ & $55.50 \pm 0.00 \mathrm{cB}$ & $59.30 \pm 0.00 \mathrm{cA}$ \\
\hline Submitted to ultraviolet radiation type $\mathbf{C}$ with acidification by lactic acid & $55.90 \pm 0.00 \mathrm{cA}$ & $50.00 \pm 0.00 \mathrm{~dB}$ \\
\hline $1000 \mathrm{~J} \mathrm{l}^{-1}$ & $55.73 \pm 0.00 \mathrm{cA}$ & $54.73 \pm 0.00 \mathrm{cA}$ \\
\hline $5000 \mathrm{~J} \mathrm{l}^{-1}$ & $63.30 \pm 0.00 \mathrm{bA}$ & $56.70 \pm 0.00 \mathrm{cB}$
\end{tabular}

There was no significant difference in the same lowercase letters in the column for the treatments and the same uppercase letters in the line, for the paste temperature used, by Tukey test at $5 \%$ probability. 
The results point to the similarity of the pre-acidified cassava starch sample treated with UV-C, beginning at 5,000 $\mathrm{J} \mathrm{l}^{-1}$, to the commercial fermented cassava starch. The speed at which the reaction occurred allows us to highlight the advantages of using a modular reactor equipped with lamp which is capable of generating $\mathrm{UV}$ radiation type $\mathrm{C}$ in a continuous flow system.

\section{Conclusion}

The results show that it is possible to obtain a substitute of polvilho azedo close to the commercial one by treating cassava starch with both lactic acid and UV-C irradiation in a continuous flow system.

It also shows that the carboxyl content can be a good indicator to evaluate the quality of modified starches by oxidizing, which is only a part of the modification that allows for the expansion of cassava fermented starch. In addition, the transparency and viscosity are only used to emphasize the modifications to the native starch, but do not allow for evaluation of the quality of the fermented cassava starch.

The expansion adopted as quality index showed that the lowest UV-C dose $\left(1,000 \mathrm{~J} \mathrm{l}^{-1}\right)$ is enough to provide the native cassava starch with the volume equivalent to the standard commercial fermented cassava starch and allows for the selection of the $5,000 \mathrm{~J}^{-1}$ dose by allowing a shorter time, which reduces costs for the industry.

With the continuous system, it is possible to avoid the problems of the traditional process of polvilho azedo with fermentation and exposure to sunlight. Its use will allow for standardization of batches and prevent contamination. Additionally, it will make possible to adjust the product to market needs, which may provide greater flexibility to industries with the possibility of including the commercial equipment between the two centrifuges on the cassava starch industry plants, which already exists in industries.

\section{References}

Association of Official Analytical Chemists - AOAC. (1997). Official methods of analysis of AOAC International (16th ed.). Gaithersburg: AOAC International.

Bertolini, A. C., Mestres, C., \& Colonna, P. (2000). Rheological properties of acidified and UV-irradiated starches. Stärke, 52(10), 340-344. http://dx.doi.org/10.1002/1521-379X(200010)52:10<340::AID-STAR340>3.0.CO;2-H

Bhat, R., \& Karim, A. A. (2009). Impact of radiation processing on starch. Comprehensive Reviews in Food Science and Food Safety, 8(2), 44-58. http://dx.doi.org/10.1111/j.1541-4337.2008.00066.x

Brito, V. H. S., \& Cereda, M. P. (2015). Método para determinação de volume específico como padrão de qualidade do polvilho azedo e sucedâneos. Brazilian Journal of Food Technology, 18(1), 14-22. http://dx.doi.org/10.1590/1981-6723.0214

Cereda, M. P. (1993). Quality evaluation Samples of fermented cassava starch (polvilho azedo). Boletim da Sociedade Brasileira de Ciência e Tecnologia de Alimentos, 17(3), 305-320.

Craig, S. A. S., Maningat, C. C., Seib, P. A., \& Hoseney, R. C. (1989). Starch paste clarity. Cereal Chemistry, 66, 173-182.

Demiate, I. M., Barana, A. C., Cereda, M. P., \& Wosiacki, G. (1999). Organic acid profile of commercial sour cassava starch. Food Science and Technology, 19(1), 131-135. http://dx.doi.org/10.1590/S0101-20611999000100024

Demiate, I. M., Dupuy, N., Huvenne, J. P., Cereda, M. P., \& Wosiacki, G. (2000). Relationship between baking behavior of modified cassava starches and starch chemical structure determined by FTIR spectroscopy. Carbohydrate Polymers, 42(2), 149-158. http://dx.doi.org/10.1016/S0144-8617(99)00152-6

Demiate, I. M., \& Kotovicz, V. (2011). Cassava starch in the Brazilian food industry. Food Science and Technology, 31(2), 388397. http://dx.doi.org/10.1590/S0101-20612011000200017

Dewi, A. M. P., Tethool, E. F., \& Jading, A. (2014). Physicochemical and baking expansion properties of peroxide oxidized sago starch with different UV irradiation. Asian Journal of Food and Agro-Industry, 7(1), 6-12.

Dias, A. R. G., Elias, M. C., Oliveira, M., \& Helbig, E. (2007). Oxidação dos amidos de mandioca e de milho comum fermentados: Desenvolvimento da propriedade de expansão. Food Science and Technology, 27(4), 794-799. http://dx.doi.org/10.1590/S0101-20612007000400019

Fiedorowicz, M., Tomasik, P., You, S., \& Lim, S. T. (1999). Molecular distribution and pasting properties of UV-irradiated corn starches. Stärke, 51(4), 126-131. http://dx.doi.org/10.1002/(SICI)1521-379X(199904)51:4<126::AID-STAR126>3.0.CO;2-N

Franco, C. M. L., Ogawa, C., Rabachini, T., Rocha, T. S., Cereda, M. P., \& Jane, J. (2010). Effect of lactic acid and UV irradiation on the cassava and corn starches. Brazilian Archives of Biology and Technology, 53(2), 443-454. http://dx.doi.org/10.1590/S1516-89132010000200025 
Hoover, R. (2001). Composition, molecular structure, and physicochemical properties of tuber and root starches: A review. Carbohydrate Polymers, 45(3), 253-267. http://dx.doi.org/10.1016/S0144-8617(00)00260-5

Jyothi, A. N., Sasikiran, K., Sajeev, M. S., Revamma, R., \& Moorthy, S. N. (2005). Gelatinisation properties of cassava starch in the presence of salts, acids and oxidising agents. Stärke, 57(11), 547-555. http://dx.doi.org/10.1002/star.200500412

Kumar, P., Ganure, A. L., Ubudhi, B. B., \& Shukla, S. (2014). Synthesis and characterization of pH sensitive amphiphilic new copolymer of methyl methacrylate grafted on modified starch: Influences of reaction variables on grafting parameters. International Journal of Pharmacy and Pharmaceutical Sciences, 6(1), 868-880.

Marcon, M. J. A., Kurtz, D. J., Raguzzoni, J. C., Delgadillo, I., Maraschin, M., Soldi, V., Reginatto, V., \& Amante, E. R. (2009) Expansion properties of sour cassava starch (polvilho azedo): Variables related to its practical application in bakery. Stärke, 61(12), 716-726. http://dx.doi.org/10.1002/star.200900132

Newport Scientific. (1998). Applications manual for the rapid visco analyser. Australy: Instrument Support Group.

Plata-Oviedo, M., \& Camargo, C. (1998). Effect of acid treatments and drying processes on physico-chemical and functional properties of cassava starch. Journal of the Science of Food and Agriculture, 77(1), 103-108. http://dx.doi.org/10.1002/(SICl)1097-0010(199805)77:1<103::AID-JSFA10>3.0.CO;2-2

Silva, R. M., Ferreira, G. F., Shirai, M. A., Haas, Â., Scherer, M. L., Franco, C. M. L., \& Demiate, I. M. (2008). Características físico-químicas de amidos modificados com permanganato de potássio/ácido lático e hipoclorito de sódio/ácido lático. Food Science and Technology, 28(1), 66-77. http://dx.doi.org/10.1590/S0101-20612008000100011

Smith, R. J., \& Paschall, E. F. (1967). Characterization and analysis of starches. In R. L. Whistler (Ed.), Starch: Chemistry and Technology (2nd ed., pp. 569-635). New York: Academic Press.

StatSoft, Inc. (2008). Statistica data analysis software system Version 7.0. Tulsa: Statsoft Inc.

Tethool, E. F., Jading, A., \& Santoso, B. (2012). Characterization of physicochemical and baking expansion properties of oxidized sago starch using hydrogen peroxide and sodium hypochlorite catalyzed by UV irradiation. Food Science and Quality Management, 10(1), 1-10.

Vatanasuchart, N., Naivikul, O., Charoenrein, S., \& Sriroth, K. (2005). Molecular properties of cassava starch modified with different UV irradiations to enhance baking expansion. Carbohydrate Polymers, 61(1), 80-87.

http://dx.doi.org/10.1016/j.carbpol.2005.02.012

Vatanasuchart, N., Naivikul, O., Charoenrein, S., \& Sriroth, K. (2003). Effects of different UV irradiations on properties of cassava starch and biscuit expansion. Witthayasan Kasetsat Witthayasat, 37(1), 334-344.

Funding: Ministério da Ciência, Tecnologia e Inovação/ Conselho Nacional de Desenvolvimento Científico e Tecnológico (CNPq Process 476216/2006-0) and Coordenação de Aperfeiçoamento de Pessoal de Nível Superior (CAPES) by the scholarship. 